\title{
Geographic Information System Mapping of Kerosene Businesses In Jayapura
}

\author{
Rachman kurniawan ${ }^{1}$, jusmawati ${ }^{2}$, Andrian Sah $^{3}$ \\ ${ }^{1,2,3}$ Program Studi Sistem Informasi, Fakultas Teknik dan Sistem Informasi, Universitas Yapis Papua \\ $\underline{\underline{I}}$ rachmankurniawan91@gmail.com; 풀. juzmaati.nr@gmail.com; ${ }^{3}$ cyberdefance23@ gmail.com
}

\begin{abstract}
Article Info
Article history:

Received 06 16, 2021

Revised 12 10, 2021

Accepted 14 12, 2021

\section{Keywords:}

Geographic

Information

System

Kerosene

QGIS

ABSTRACT

The role of BBM is very important in people's lives. Fuel is a basic need for rural and urban communities, both as household needs and as business needs. The existence of kerosene in Jayapura is quite evenly distributed. From the results of survey conducted by the OFFICE OF INDUSTRY, COOPERATIVE TRADE AND SMEs that every year the use of LPG as fuel for cooking is still very low, while the use of kerosene from year to year is widely used by local community, it causes more kerosene bussiness but people have difficulty getting information about the location to get the kerosene, therefore we need a system that can help find the location, namely geographic information system that can provide information about fuel oil base points. This system is in symbols form for making the system using QGIS with the PIECES analysis method, the design using Unified Modeling Language (UML) method and the development method using waterfall method. This research produces a system that can be expected to make it easier for the public to know the distribution of kerosene in Jayapura.
\end{abstract}

This is an open access article under the $\underline{C C B Y-S A}$ license.

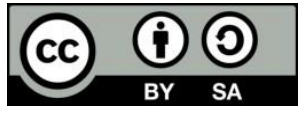

\section{Corresponding Author:}

Rachman kurniawan

Program Studi Sistem Informasi, Fakultas Teknik dan Sistem Informasi

Universitas Yapis Papua

Papua, Indonesia

Email: rachmankurniawan91@gmail.com

(C) The Author(s) 2021

\section{Introduction}

The role of BBM is very important in people's lives. Fuel is a necessity basic needs for rural and urban communities, both as household needs and as business needs. It also become one of the important factors for the industrial and transportation sectors.

Jayapura as the capital city of Papua Province. It is the center of government, economic, socio-political and cultural activities. The existence of kerosene bases in Jayapura is spread in various places, but until now there is no geographical description of its location. From the results of survey conducted by the OFFICE OF INDUSTRY, COOPERATIVE TRADE AND SMEs that every year the use of LPG as fuel for cooking is still small used and its used for businesses in the food sector, while the use of kerosene from year to year is widely used in local communities, it proof that more kerosene bussiness arise in adays.

Most people only know the place and do not know the location of kerosene bases. In Jayapura, there are many existing kerosene bases, but the community has difficulty getting information about the location to obtain that kerosene. Usually people know this information only by mouth to mouth. Less information geographically, make people have to look for kerosene bases in that area or elsewhere to obtain the kerosene as the neededs. 
For this reason, technology is needed to support in getting information by using geographic information system to make easy for the public to know the distribution points of oil bases in Jayapura, so that people can easily get kerosene.

\section{Methodology}

Geographic information system is a system designed to store, manipulate, analyze, and manage all types of geographic data [1][2]. Quantum GIS is a project of OSGeo, a non-profit and non-governmental organization whose goal to unite various geospatial communities from various parts of the world [3].

2.1. Research methodology

2.1.1. Data Collection

This research uses data collection methods, they are: interviews, observations and literature studies. 1. Interview

Interview is a dialogue with a specific purpose between two parties to obtain accurate data from the right sources [4]. Interview was conducted with the Head of TRADE of Papua province. He is a person in checking the verification and validation of files.

2. Observation

Observation is a data collection methods by directly observing the situation [5]. In this research, it conduct directly into the field to take coordinates.

2.1.2. Analysis Method

The system analysis method used in this research is PIECES method. PIECES method is a way of recognizing an Information System of performance, information, economics, control, efficiency and service. This method was chosen to describe the exist problems that exist in the old system or the running system into several aspects such as aspects of performance, information, economy, control, efficiency, and service [6].

2.1.3. Design Method

The design method used in this research is Unified Modeling Language (UML). UML can make problem solving in making website-based designs. UML method used in this research consist of four types, namely Use Case Diagrams, Class Diagrams, Sequence Diagrams and Activity Diagrams.

2.1.4. Development Method

The development method used in this research is Waterfall method. This method takes a systematic approach where the work of a system is carried out sequentially and gradually or in phases. Every phases must be completed first before continue the next phase to avoid repetition and to make easy in repairing if an error occurs [7].

\subsubsection{Testing Method}

The testing method used in this research is blackbox testing, it focuses on the functional requirements of the software to find out the system response [8]. From the response of the system, it can be seen whether the system has been running well or not as desired by the user.

\subsection{System planning}

The system design is designed after analyzing the running system. The design of this system consists of process design and database design.

\subsubsection{Process Design}

The process design on this system is designed using Unified Modeling Language (UML) which consists of Use Case Diagrams, Class Diagrams, Sequence Diagrams and Activity Diagrams.

\section{Use Case Diagram}

Use case diagram is a description of interaction between actors and system [9]. The proposed use case diagram for this system includes actors and public. The proposed use case diagram can be seen in the following figure.

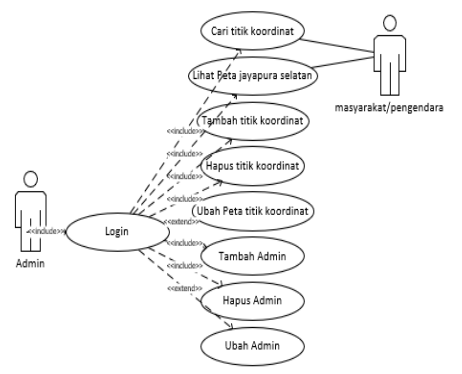

figure 1 Use Case Diagram 


\section{Class Diagram}

Class Diagram describes the static structure of the classes in the system and describes the properties, operations and relationships between classes [10]. The proposed class diagram for this system can be seen in the following figure.

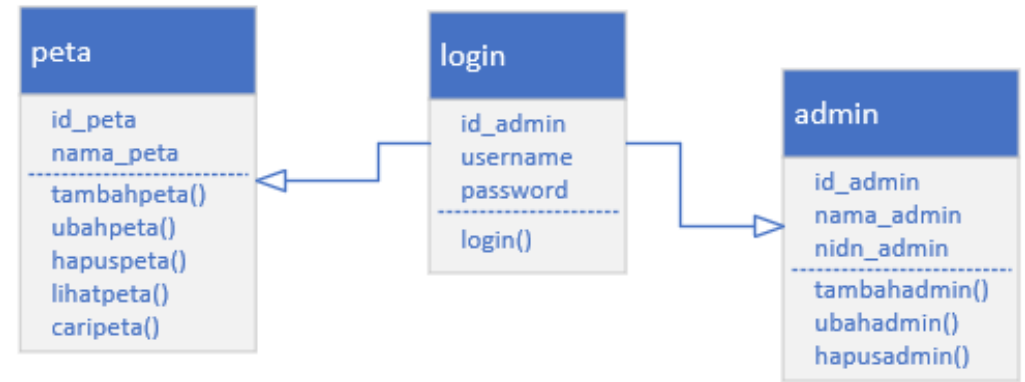

Figure 2 Class Diagram

\section{Sequence Diagram}

Sequence Diagrams describes the interactions between objects in and around the system including users and views. The sequence diagram proposed in this system includes a business entity sequence diagram and a family group diagram. The proposed sequence diagram for this system can be seen in the following figure.

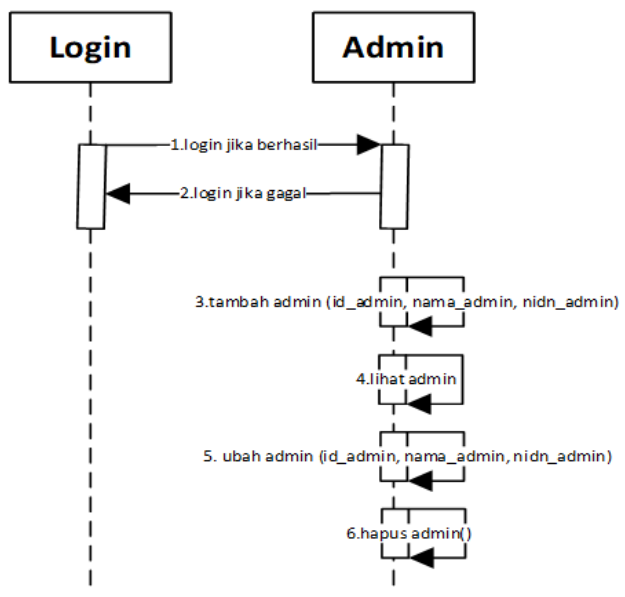

Figure 3 Sequence Diagram of Business Entity

Admin must login first to be able to add, change, delete and search for business entities.

Admin, VVA team leader and general chairman must first login to be able to search, view, print SBU application and print SBU application report.

4. Activity Diagram

Activity Diagrams describe the flow of various activities in the designed system and find out what data is needed to be processed in the system. The proposed activity diagram can be seen in the following figure.

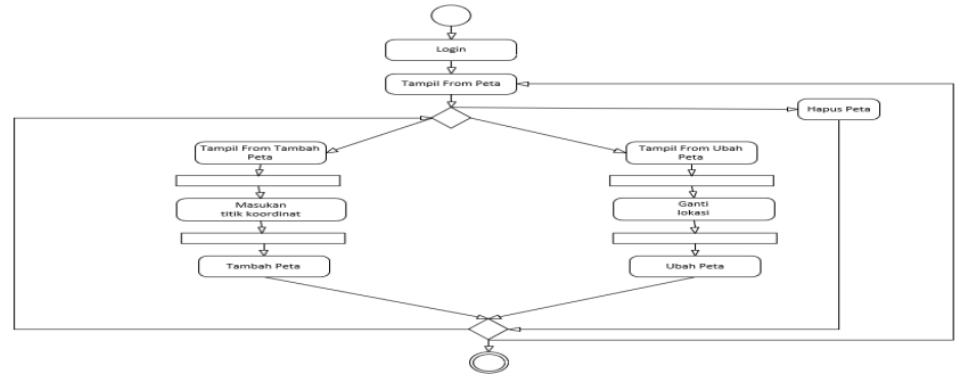


In the business entity activity diagram there are several activities that can be done, they are: add, change, delete and search for business entities.

In the activity diagram of Figure 5. Admin explains, where the admin must login first. The activity in the admin page appears is to add admin, it is done by admin which consists of entering id_admin, admin_name, nidn_admin. Another activity is to change admin, it is done by admin which consists of changing id_admin, admin_name, nidn_admin. The last activity is to delete admin, it will be done by admin also.

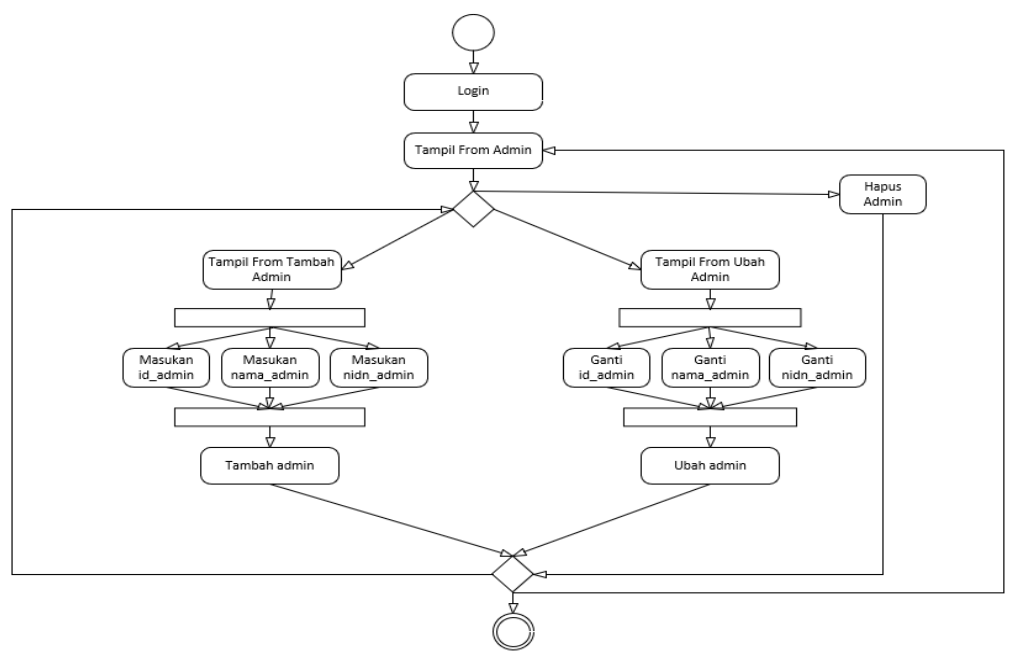

Figure 6 Activity Diagram of Map

\section{Result and Discussion}

\subsection{Login Page View}

The login page is the main display in this system. Before entering the main page, the user must first login. This page can be accessed by the user by entering the username and password.

\section{Login}

\begin{tabular}{l} 
Username \\
Nsemame \\
Password \\
Password $\rightarrow$ Masuk \\
\hline
\end{tabular}

Figure 8 Login Page View

\subsection{Main Page View}

After the admin logs in, the main menu page will be displayed. The main menu page will display a map of the southern city of Jayapura when zoomed out
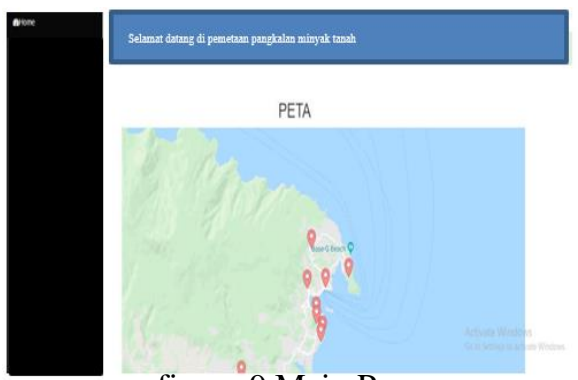

figure 9 Main Page

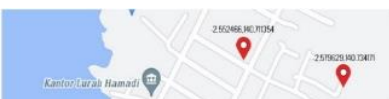

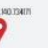


Figure 10 zoom in page

\section{Conclusion}

It can be concluded that the existence of Geographic Information System can help the society in finding kerosene bases so that people who need it can find that location and that palces.

In order for this system to function more optimally, there are several suggestions as follows:

1. System development is needed to add the Dijkstra Algorithm feature to find the closest distance

2. Android-based system development is needed to make it more attractive

3. It is also necessary to add a notification feature.

\section{References}

[1] D. Puastuti and K. S. Abb, "PERANCANGAN SISTEM INFORMASI PENDATAAN WARGA SEKOLAH BERBASIS WEB PADA SDN 2 PAGELARAN,” vol. 3, no. 1, pp. 26-42,2017.

[2] Nofri Wandi Al Hafiz and M. Hasim Siregar, "GEOGRAPHIC INFORMATION SYSTEMS FOR THE DISTRIBUTION OF COMMUNITY SERVICE ACTIVITIES IN KUANTAN SINGINGI DISTRICT”, infokum, vol. 10 , no. 1 , pp. $236-243$, Dec. 2021

[3] T. H. Ningrum, M. K. G. Umar, and . S., "Sistem Informasi Penerimaan Berkas Badan Usaha Jasa Konstruksi pada Lembaga Pengembangan Jasa Konstruksi (LPJK) Provinsi Maluku Utara," J. Ilm. Ilk. - Ilmu Komput. Inform., vol. 3, no. 1, pp. 43-51, 2020, doi: 10.47324/ilkominfo.v3i1.93.

[4] F. Yunita, “Analisa Dan Perancangan Sistem Informasi Izin Usaha Jasa Konstruksi,” J. Sist., vol. 6, no. September, pp. 52-59, 2017.

[5] A. Aliman, "Sistem Informasi Database Sertifikat Keterampilan Kerja (SKTK) pada LPJKD Aceh berbasis Web," J. JTIK (Jurnal Teknol. Inf. dan Komunikasi), vol. 4, no. 2, p. 75, 2020, doi: 10.35870/jtik.v4i2.118.

[6] C. Andari, D. R.-I. pdfa. Wijaya, and R. Budiawan, "Aplikasi Pendataan Kendaraan Hilang Berbasis Web ( Studi Kasus: Polres Cimahi )," vol. 1, no. 1, pp. 542-546, 2015.

[7] R. P. Ardhiyani and H. Mulyono, "INFORMASI PARIWISATA BERBASIS WEB SEBAGAI MEDIA PROMOSI PADA KABUPATEN TEBO,” vol. 3, no. 1, pp. 952-972,2018.

[8] F. S. Ariansyah; Fajriyah; Prasetyo, "RANCANG BANGUN SISTEM INFORMASI PENDATAAN ALUMNI PADA STIE PRABUMULIH BERBASIS WEBSITE DENGAN MENGGUNAKAN BOOTSTRAP,” vol. 17, no. $1,2017$. 